\title{
CHAPTER 12 \\ THE INTELLECTUAL-KNOWLEDGE IMPERATIVE OF THE GLOBAL ECONOMY IN THE 21ST CENTURY
}

\section{Nyameshchuk A. V.}

\section{INTRODUCTION}

The end of the twentieth century marked the formation of a global model of economic development as a result of gradual fundamental transformation processes in the world economy. The combination of world economic entities in a single international economic system in accordance with the trends of global economic development (integration, transnationalization, socialization, institutionalization and strategic orientation to innovation) defines the new disposition of countries on the economic map of the world. Sovereign states are forced to adjust foreign policy, develop strategies to adapt to current performance criteria, to find their place in the new model of international distribution of labor and their own niche in international markets.

But at the turn of the second and third millennium, the world economy faced information and communication technologies revolution, resulting in cheaper and more reliable communications, new information management software, powerful personal computers the proliferation of which is growing rapidly. If in the mid-1990s the number of mobile cellular subscribers averaged 2 per 100 people, and the proportion of those using the Internet fluctuated within $1 \%$ of the total population, in 2000 the value of these indicators reached 17 people and $9 \%$ respectively. In the first half of 2010, the upward trend in these indicators accelerated due to the emergence of mobile, portable devices that provided Internet access and the gradual decline of fixed telephony technologies. In 2017, the percentage of the world population using the Internet came close to $45 \%$, and the proportion of mobile cellular subscribers per 100 people exceeded $100 \%{ }^{1}$.

Under new conditions, there is a redistribution of world economic power: the triad countries that formed the core of the world economy

\footnotetext{
${ }^{1}$ World Bank Group (2020). World Development Report 2020: Trading for Development in the Age of Global Value Chains, Washington: World Bank Publications. Retrieved from: https://openknowledge.worldbank.org/handle/10986/32437 (accessed 01.12.2019).
} 
of the twentieth century (the USA, Japan and the European Union) are inferior to global markets for countries that are effectively implementing strategies of intellectual breakthrough and maximum mobilization of the national resource base undergoing the formation of branches of the sixth technological way (China, India, Hong Kong, Brazil, Singapore, India, South Korea, and some countries in the Middle East). Modification of the model of world economic power is accompanied by exacerbation of socio-economic contradictions between the subjects of the global economy, which is manifested in the following: stratification of segments of the economy by technological structures (parallel existence of agrarian raw materials, industrial and postindustrial), and specific enclaves and innovation economics); complication of the structure of the economic system based on the differentiation of sectoral sectors (development of the virtual sector and creative industries) and subjects of the global economy (national states, integration groups, international organizations, cities-leaders, clusters, international companies and individuals which are able to influence the dynamics of global economic development scientists, Nobel laureates, university professors, prominent financiers, entrepreneurs, etc. $)^{2}$.

Taking into account these changes, it is appropriate, in our view, to analyze innovative developments in today's global markets; methodological identification of key concepts of global economy intellectualization process and identification of features of extended reproduction cycle of an intellectual product.

\subsection{Innovative shifts in today's global markets}

According to the world institutions dealing with issues of globalization, since the beginning of the 21 st century. The fourth phase of economic globalization has begun, the peculiarities of which are the multipolarity of the world economy and the use of digital technologies in production, services ${ }^{3}$.

\footnotetext{
2 Luk'yanenko D., Poruchnik A., Kolesov V. (ed.) (2013) Global'noe ekonomicheskoe razvitie: tendentsii, asimmetrii, regulirovanie [Global economic development: trends, asymmetries, regulation: monograph]. Kyiv: KNEU. (in Russian).

${ }^{3}$ Bhattacharya A., Bürkner H.-P., Bijapurkar A. (2016). What you need to know about globalization's radical new phase. BCG Henderson Institute. Retrieved from: https:/www.bcg.com/publications/ 2016/globalization-growth-what-need-know-globalization-radical-new-phase.aspx (accessed 27 December 2019); International Bank for Reconstruction and Development / World Bank (2002). Globalization, Growth, and Poverty. A World Bank Policy Research Report. Washington - New York: a copublication of the World Bank and Oxford University Press. Retrieved from: http://documents.worldbank.org/ curated/en/954071468778196576/pdf/multi0page.pdf (accessed 29 December 2019).
} 
The defining direction of civilizational development since the end of the second millennium AD is the innovative vector ${ }^{4}$. Noting that innovations «... lead to deterioration in product performance, at least in the short term», but subsequently become «fully competitive in the same market» due to being «cheaper, simpler, smaller in size and easier to use, even if «the product improvement pace outstrips the growth of consumer needs», we are witnessing a breakthrough in new technologies 5 . To illustrate his statement, K. Christensen cites the emergence of light motorcycles Honda, Kawasaki and Yamaha in the markets of North America and Europe, which are considered as breakthrough technology for powerful Harley off-road motorcycles Davidson and BMW, the invention of transistors breakthrough, vacuum tubes Targeted and Walmart merchandise for supermarket purchases. Identifying the term «innovation» as «any combination of activities or technologies that breaks existing trade-offs to achieve results in such a way as to widen the scope of the possible» ${ }^{6}$, the nature of innovation can be recognized as destructive to the existing, established order. Movement and change, as a consequence, are typical phenomena of history, and therefore of economics. In our view, the movement to any direction, to any landmark, has, in the end, certain changes, adaptation to which promotes invention and development, which can be measured by economic indicators of income and expenses.

The steady tendency to invest in the development of science and technology has led to the end of $20^{\text {th }}$ beginning of $21^{\text {st }}$ century a significant change in the global landscape of research, education and business, which is considered the beginning of a new civilization era postindustrial. The value reorientation of society from the dominant economic features of the industrial development system to the «system of intellectually-creative coordinates»", defines the new

\footnotetext{
${ }^{4}$ Bhattacharya A., Khanna D., Schweizer C., Bijapurkar A. (2017). The New Globalization: Going Beyond the Rhetoric. BCG Henderson Institute. Retrieved from: https://www.bcg.com/publications/ 2017/new-globalization-going-beyond-rhetoric.aspx (accessed 21 December 2019); Deloitte Development LLC (2015). Patterns of disruption: anticipating disruptive strategies in a world of unicorns, black swans, and exponentials. Bratislava: Deloitte University Press. Retrieved from: https://www2.deloitte.com/content/dam/Deloitte/nl/Documents/technology/deloitte-nl-deloitte-patternsof-disruption.pdf (accessed 17 November 2019).

${ }_{5}^{5}$ Christensen C. M. (2012). The innovator's dilemma: when new technologies cause great firms to fail. London: HarperCollins Publishers. Retrieved from: https://pdfs.semanticscholar.org/ ca36/98315441292596205d44d1a775d9cfc3fe37.pdf___(accessed 4 December 2019). DOI:10.15358/9783800642816.

${ }^{6}$ Raynor M. (2013). Introducing perspectives on innovation. Deloitte Consulting. Retrieved from: http://dupress.com/articles/introducing-on-innovation (accessed 10 December 2019).

Luk'yanenko D., Poruchnik A., Kolesov V. (ed.) (2013). Global'noe ekonomicheskoe razvitie: tendentsii, asimmetrii, regulirovanie [Global economic development: trends, asymmetries, regulation: monograph]. Kyiv: KNEU (in Russian).
} 
foundations of civilizational progress: the broad intellectualization of production, the priority development of science, the development of complex intellectual labor. The information-technological mode of production, which dominates at the present stage of civilizational development, is characterized by processes of informatization, electrification, computerization and robotization. Intellectual works, especially research in the field of science and technology and their commercialization, become the basis of modern economics, and the economy itself becomes intellectual, knowledge- and scientifically intensive.

The strategic orientation of the global economy to innovation tightly links the competitiveness of national economies with the effectiveness of adherence to technological progress, which dramatically altered the distribution of economic opportunities. Recognizing innovation as a major lever of economic growth today, it is impossible to ignore the destabilizing effects of super-rapid technological development, known as digitization, digitalisation of the global economy, or the Economy 4.0 phenomenon ${ }^{8}$. Among the interventions that increase «fragility» in the technological sphere, $\mathrm{N}$. Taleb calls neomania, «the love of change and the new for the sake of change and the new; predicting the future by adding, not subtracting,» which can also result in alienation and dulling ${ }^{9}$.

Digital technologies, along with geopolitical and socio-economic shifts, have changed the course of globalization and led to contradictory facts about its development. According to the World Bank Group, the recession of the global economy continues during 2010-2019: the growth rate of the global gross product decreases (in $20173.2 \%$, in $20183.0 \%$, in 2019 (preliminary data) 2, 4\%), world trade volume (in $20184.0 \%, 2019$ (preliminary data) 1.4\%) and investment flows ${ }^{10}$. On the other hand, during this same period, fundamentally new forms of business emerged, which were able to predict and capture models of innovative destruction in global markets in a timely manner (Table 1 ).

\footnotetext{
${ }^{8}$ World Economic Forum (2019). Policy Pathways for the New Economy. Shaping Economic Policy in the Fourth Industrial Revolution. Geneva: World Economic Forum. Retrieved from: http://www3.weforum.org/docs/WEF_Policy_Pathways_for_the_New_Economy.pdf (accessed 27 November 2019).

${ }^{9}$ Taleb N. N. (2018). Antykrykhkistj. Pro (ne)vrazlyve u realjnomu zhytti [Antifragile. Things that Gain from Disoder] / trans. from English. M. Kdymchuk. - Kyiv: Nash format (in Ukrainian).

${ }^{10}$ A World Bank Group (2020). Global Economic Prospects. Slow Growth, Policy Challenges. Washington: World Bank Publications. Retrieved from: https://www.worldbank.org/en/news/feature/2020/01/08/january-2020-global-economic-prospects-slowgrowth-policy-challenges (accessed 9 January 2020).
} 
Table 1

Basic models of innovative destruction in today's global markets *

\begin{tabular}{|c|c|c|}
\hline Catalysts & Risks & $\begin{array}{c}\text { Examples of } \\
\text { successful } \\
\text { adaptation }\end{array}$ \\
\hline \multicolumn{3}{|c|}{$\begin{array}{c}\text { Increasing the number of consumers and manufacturers through the use of } \\
\text { virtual distribution channels }\end{array}$} \\
\hline $\begin{array}{l}\text { A digital infrastructure } \\
\text { that gives access to } \\
\text { sophisticated production } \\
\text { facilities } \\
\text { Personalized products } \\
\text { Reduction of barriers to } \\
\text { entry and a favorable } \\
\text { regulatory policy }\end{array}$ & $\begin{array}{l}\text { Decrease in profit margins; } \\
\text { receipts from physical } \\
\text { distribution channels; values } \\
\text { of investments in assets of } \\
\text { retail trade, production and } \\
\text { logistics; } \\
\text { Changing perceptions about } \\
\text { the need for physical assets }\end{array}$ & $\begin{array}{l}\text { e-commerce } \\
\text { Sale of audio and } \\
\text { video content }\end{array}$ \\
\hline \multicolumn{3}{|c|}{ Access to underutilized assets of adjacent markets } \\
\hline $\begin{array}{l}\text { Digital infrastructure } \\
\text { Sensors for advanced } \\
\text { analytics in real time; } \\
\text { from ownership to access } \\
\text { rights }\end{array}$ & $\begin{array}{l}\text { Sustainability of low-use } \\
\text { asset maintenance costs } \\
\text { Decrease of economic } \\
\text { expediency of acquisition of } \\
\text { valuable assets }\end{array}$ & $\begin{array}{l}\text { Hospitality and } \\
\text { hotel business }\end{array}$ \\
\hline \multicolumn{3}{|c|}{ Transformation of products into platforms } \\
\hline $\begin{array}{l}\text { Digital infrastructure } \\
\text { from consumers to users } \\
\text { through training and } \\
\text { aggregation platforms }\end{array}$ & $\begin{array}{l}\text { Standardized Product } \\
\text { Revenue declines } \\
\text { Impairment of production } \\
\text { capacity } \\
\text { Changing perceptions of who } \\
\text { is a partner, not a competitor }\end{array}$ & $\begin{array}{l}\text { Mobile Software, } \\
\text { PC Operating } \\
\text { Systems }\end{array}$ \\
\hline \multicolumn{3}{|c|}{ Peer-to-peer interaction or peer interaction } \\
\hline $\begin{array}{l}\text { Creating digital } \\
\text { technologies } \\
\text { From information } \\
\text { ownership (protection) } \\
\text { and inside control to } \\
\text { open information flows } \\
\text { (sharing) and trust } \\
\text { between businesses }\end{array}$ & $\begin{array}{l}\text { Decrease in revenue from } \\
\text { patented products } \\
\text { Depreciation of own assets } \\
\text { that contributed to } \\
\text { centralization and } \\
\text { concentration of power }\end{array}$ & $\begin{array}{l}\text { Distributed control } \\
\text { systems } \\
\text { Digital Markets } \\
\text { Streaming services }\end{array}$ \\
\hline \multicolumn{3}{|c|}{$\begin{array}{l}\text { Distributed product development } \\
\end{array}$} \\
\hline $\begin{array}{l}\text { Digital infrastructure } \\
\text { From passive consumer } \\
\text { to active participant } \\
\text { based on training and } \\
\text { aggregation platforms }\end{array}$ & $\begin{array}{l}\text { Lack of income from the } \\
\text { main activity and the need to } \\
\text { eliminate existing production } \\
\text { facilities } \\
\text { Changing perceptions of } \\
\text { what the role of third parties } \\
\text { is }\end{array}$ & $\begin{array}{l}\text { Online libraries } \\
\text { and encyclopedias, } \\
\text { maps, travel } \\
\text { guides, digital } \\
\text { music players }\end{array}$ \\
\hline
\end{tabular}




\begin{tabular}{|c|c|c|}
\hline Catalysts & Risks & $\begin{array}{l}\text { Examples of } \\
\text { successful } \\
\text { adaptation }\end{array}$ \\
\hline \multicolumn{3}{|c|}{ Transformation of goods and services into a package of goods and service } \\
\hline $\begin{array}{l}\text { A digital infrastructure } \\
\text { that gives access to } \\
\text { sophisticated production } \\
\text { facilities } \\
\text { From «more than you } \\
\text { want» to «just what you } \\
\text { want» } \\
\text { Market growth due to } \\
\text { aggregation platforms }\end{array}$ & $\begin{array}{l}\text { Decrease in revenue as a } \\
\text { result of market entry at a } \\
\text { competitive price } \\
\text { The need to eliminate } \\
\text { existing production facilities } \\
\text { and distribution } \\
\text { infrastructure; change of the } \\
\text { image that is valued by the } \\
\text { consumers }\end{array}$ & $\begin{array}{l}\text { Media players for } \\
\text { the operating } \\
\text { system } \\
\text { Online ads, } \\
\text { Wireless } \\
\text { messaging systems }\end{array}$ \\
\hline \multicolumn{3}{|c|}{ Value chains reduction } \\
\hline $\begin{array}{l}\text { Digital infrastructure and } \\
\text { cheaper physical, digital } \\
\text { distribution technologies; } \\
\text { Consolidation of } \\
\text { consumer purchasing } \\
\text { power through } \\
\text { aggregation platforms }\end{array}$ & $\begin{array}{l}\text { Decreasing revenue from } \\
\text { existing distribution channels } \\
\text { and product configurations } \\
\text { Need to eliminate existing } \\
\text { production facilities, } \\
\text { equipment }\end{array}$ & $\begin{array}{l}\text { Digital cameras } \\
\text { Personal } \\
\text { computers } \\
\text { Furniture and } \\
\text { interior design }\end{array}$ \\
\hline \multicolumn{3}{|c|}{ Matching the price and usage $\mathrm{f}$ a product } \\
\hline $\begin{array}{l}\text { Digital infrastructure; } \\
\text { sensors for advanced } \\
\text { analytics in real time; } \\
\text { from property rights to } \\
\text { access rights; avoiding } \\
\text { down payments }\end{array}$ & $\begin{array}{l}\text { Creating unique assets from } \\
\text { "zero"; dilution of revenue } \\
\text { due to refusal from advace } \\
\text { payment; } \\
\text { Perception change of the } \\
\text { product value and product } \\
\text { deliverery }\end{array}$ & $\begin{array}{l}\text { Customer } \\
\text { relationship } \\
\text { management } \\
\text { systems; «SaaS», } \\
\text { «PaaS», «IaaS» } \\
\text { models; server } \\
\text { computers }\end{array}$ \\
\hline \multicolumn{3}{|c|}{ Products integration } \\
\hline $\begin{array}{l}\text { Invention and } \\
\text { standardization based on } \\
\text { smaller, faster, cheaper } \\
\text { components; from desire } \\
\text { to get the best to adopting } \\
\text { a basic, more affordable, } \\
\text { universal product }\end{array}$ & $\begin{array}{l}\text { Need to eliminate } \\
\text { existing production } \\
\text { facilities; } \\
\text { Perception change of } \\
\text { consumer value and } \\
\text { form-factor }\end{array}$ & $\begin{array}{l}\text { Microchips and } \\
\text { wireless units; } \\
\text { smartphones, portable } \\
\text { navigation devices }\end{array}$ \\
\hline
\end{tabular}

* summarized by author from sources ${ }^{11}$

${ }^{11}$ Deloitte Development LLC (2015). Expand market reach: connecting fragmented buyers and sellers-wherever, whenever. Bratislava: Deloitte University Press. Retrieved from: https://www2.deloitte.com/content/dam/insights/us/articles/disruptive-strategy-market-reach-digitalmarketplaces/DUP_1459_Expand-market-reach_vFINAL.pdf (accessed 27 October 2019); Deloitte Development LLC (2015). Unlock assets from adjacent markets: cultivating opportunities on the edge. Bratislava: Deloitte University Press. Retrieved from: https://www2.deloitte.com/content/dam/ insights/us/articles/disruptive-strategy-unlock-assets-adjacent-markets/DUP_3059_Unlock-adjacentassets_vFINAL.pdf (accessed 24 December 2019); Deloitte Development LLC (2015). Turn products into product platforms: providing a foundation for others to build upon. Bratislava: Deloitte University 
The analysis of the Table 1 allows us to argue that the main catalysts for innovation in today's global marketplace are the proliferation of digital technologies as the basis for digital infrastructure, the emergence of a platform business model and the rethinking of consumer roles. As an example of businesses that emerged from the successful acquisition of catalysts for innovative change and a rethinking of strategic vision, unicorns, organizations specializing in the development of exponential technologies, and a platform business model can be called.

Technology companies operate on the principle of «smaller, faster, more powerful, but also cheaper», which results in the destruction of businesses with less technologically ready competitors. The amount and real amount of money raised by private companies tech startups that, according to PitchBook, CB Insights, Fortune news feeds and own research, have crossed the $\$ 1$ billion limit. As of January 2015, the number of «unicorns» was 80 companies $^{12}$, and in January 2016, their number exceeded 170 companies $^{13}$, and formed a group of so-called. «Decacorns» companies whose valuation exceeded $\$ 10$ billion $^{14}$. The first "decayer" venture capitalists call Facebook, the value of which reached $\$ 10$ billion in 2013. In January 2016, the Decare Group had 13 companies, led by Uber worth $\$ 62$ billion.

\footnotetext{
Press. Retrieved from: https://www2.deloitte.com/content/dam/insights/us/articles/disruptive-strategyproduct-platforms/DUP_3056_Products-to-platforms_v2.pdf (accessed 25 November 2019); Deloitte Development LLC (2016). Connect peers: leveraging the evolving digital infrastructure to empower the edge. Bratislava: Deloitte University Press. Retrieved from: https://www2.deloitte.com/content/ dam/insights/us/articles/3061_Patterns-of-disruption-connect-peers/DUP_Patterns-of-disruption-connectpeers.pdf (accessed 25 November 2019); Deloitte Development LLC (2015). Distributed product development: Mobilizing many to create one. Bratislava: Deloitte University Press. Retrieved from: https://www2.deloitte.com/content/dam/insights/us/articles/disruptive-strategy-distributed-productdevelopment/DUP_1461_Distributed-product-development_vFINAL.12.2.pdf (accessed 11 November 2019); Deloitte Development LLC (2015). Unbundle products and services: giving you just what you want, nothing more. Bratislava: Deloitte University Press. Retrieved from: https://www2.deloitte.com/ content/dam/insights/us/articles/disruptive-strategy-unbundling-strategy-stand-alone-

products/DUP_3033_Unbundle-products_v2.pdf (accessed 1 December 2019); Deloitte Development LLC (2015). Shorten the value chain: mransforming the stages of value delivery. Bratislava: Deloitte University Press. Retrieved from: https://www2.deloitte.com/content/dam/insights/us/articles/disruptivestrategy-value-chain-models/DUP_3057_Shorten-the-value-chain_v2.pdf (accessed 27 November 2019); Deloitte Development LLC (2015). Align price with use: reducing up-front barriers with usage-based pricing. Bratislava: Deloitte University Press. Retrieved from: http://emprenderioja.es/files/recurso/ dup_3058_align-price-with-use_v2.pdf (accessed 22 October 2019); Deloitte Development LLC (2015). Converge products: making $\bar{l}+1>2$. Bratislava: Deloitte University Press. Retrieved from: https://www2.deloitte.com/content/dam/insights/us/articles/disruptive-strategy-convergence-ofproducts/DUP_1465_Converge-products_vFINAL.pdf (accessed 6 December 2019).

12 Fortune (2015). The Unicorn List. Retrieved from: https://fortune.com/unicorns/2015/search/ ?valsort=desc (accessed 13 January 2020).

13 Fortune (2016). The Unicorn List. Retrieved from: https://fortune.com/unicorns/ (accessed 13 January 2020).

${ }_{14}$ Griffith E., Primack D. (2015). The age of unicorns. Fortune. Retrieved from: http://fortune.com/2015/01/22/the-age-of-unicorns/ (accessed 13 January 2020).
} 
Exponential organizations embody a business model that predicts exponential growth in productivity, profitability, and market share while reducing the number of working and used physical resources, lacking business experience, and abandoning standard competitive strategies. Due to this, a significant increase in the performance characteristics and functionality of each subsequent generation of the product is ensured with a slow increase in its price (ie, an increase in productivity by orders of magnitude higher than the price increase). Greater flexibility and dynamism compared to large linear companies allows exponential organizations to be competitive even in the following circumstances: the loss of business competence has been reduced from 30 years in 1984 to 5 years in 2014, the average lifespan of companies in the list The S\&P 500 ranged from 67 in 1920 to 15 in 2014, with Fortune 500 companies reaching $\$ 1$ billion in market cap. USA from, on average, 20 years in the twentieth century, up to, in some cases, 1 year in the second decade of the 21 st century ${ }^{15}$.

The list of unicorn companies is closely intertwined with the list of exponential companies, so the risks of further development are common to them. Venture capital market experts acknowledge that the expectations of significant returns and rapid market capitalization on them by tech start-up investors are comparable to the degree of vulnerability of this business. In particular, Hortonworks' aggressive investment fundraiser specializing in open source software development, Box storage and the Fab e-commerce site failed to deliver «unicorns» of declared cost metrics ${ }^{16}$. The facts indicate the disproportionate impact of today's technology companies on macroeconomic dynamics: Google and Amazon represent the relevant global markets ${ }^{17}$; the market capitalization of the largest technology companies largely determines the state of the global stock market, since during the period from August 2018 to January 2020, their value reached \$ 1 trillion. United States: Apple \$1.38 trillion, Microsoft \$ 1.27 trillion, Alphabet \$1.001 trillion, Amazon \$931 billion ${ }^{18}$. Such

\footnotetext{
15 Ismail S., Malone M. S., van Geest Y. (2019). Exponential Organizations: Summary and Review. Retrieved from: https://lifeclub.org/books/exponential-organizations-salim-ismail-michael-s-malone-yurivan-geest-review-summary (accessed 11 January 2020).

${ }^{16}$ Griffith E., Primack D. (2015). The age of unicorns. Fortune. Retrieved from: http://fortune.com/2015/01/22/the-age-of-unicorns/ (accessed 13 January 2020).

${ }^{17}$ Ismail S., Malone M. S., van Geest Y. (2019). Exponential Organizations: Summary and Review. Retrieved from: https://ifeclub.org/books/exponential-organizations-salim-ismail-michael-s-malone-yurivan-geest-review-summary (accessed 11 January 2020).

18 Denis-19 (2020). Rynochnaya stoimost' Alphabet vpervye prevysila \$1 trln. [Alphabet's market value exceeded \$ 1 trillion for the first time]. Khabr - soobshchestvo IT-spetsialistov [Habr - .NET Knowledge Base]. Retrieved from: https://habr.com/ru/news/t/484298/ (accessed 17 January 2020) (in Russian).
} 
high market value indicators have so far been recorded only with the oil companies PetroChina and Saudi Aramco ${ }^{19}$.

\subsection{Identification of key concepts of the global economy intellectualization}

As a result of the World Economic Forum (WEF) meetings in November 2019, economic growth in both developed and developing countries is projected to be $80-90 \%$ driven by productivity gains over the next four decades. turn is directly dependent on innovation. However, against the backdrop of this dynamic, there are three problems associated with innovation. First, in the years 2001-2013, the economy widened in performance by star companies that were able to take advantage of global presence (access to investment, resources, markets, talent) and all other companies that were stagnant (mostly in the service sector). The 5:95 star-to-other ratio has led to a slower overall productivity growth rate in the global economy and, in some countries, to nearly $0^{20}$. Secondly, the predominance of private interests in the innovation activity of global business structures, while continuing to not interfere in solving social problems of society (climate change, education, health care, etc.) has led to the decline of the basic sciences, the distortion of the orientations of civilizational development, and underpinning many national economies, making them fragile. And third, the unpredictability, unmanageability of a particular group of innovations threatens the ethical norms of society (in particular, the invention and development of artificial intelligence, the recognition of work by people by gender and ethnicity, genetic engineering, etc.).

Relying on research ${ }^{21}$, we consider it advisable to speak about the intensification of the processes of intellectualization of the global

\footnotetext{
${ }^{19}$ Lyons K. (2019). Google parent Alphabet is now a $\$ 1$ trillion company. The Verge. Retrieved from: https://www.theverge.com/2020/1/16/21069458/google-alphabet-trillion-dollar-market-cap-applemicrosoft (accessed 16 January 2020).

${ }^{20}$ World Economic Forum (2019). Policy Pathways for the New Economy. Shaping Economic Policy in the Fourth Industrial Revolution. Geneva: World Economic Forum. Retrieved from: http://www3.weforum.org/docs/WEF_Policy_Pathways_for_the_New_Economy.pdf (accessed 27 November 2019).

${ }^{21}$ Bhattacharya A., Khanna D., Schweizer C., Bijapurkar A. (2017). The New Globalization: Going Beyond the Rhetoric. BCG Henderson Institute. Retrieved from: https://www.bcg.com/publications/2017/ new-globalization-going-beyond-rhetoric.aspx (accessed 21 December 2019); Bhattacharya A., Bürkner H.-P., Bijapurkar A. (2016). What you need to know about globalization's radical new phase. BCG Henderson Institute. Retrieved from: https://www.bcg.com/publications/2016/globalization-growthwhat-need-know-globalization-radical-new-phase.aspx (accessed 27 December 2019); World Economic Forum (2019). Policy Pathways for the New Economy. Shaping Economic Policy in the Fourth Industrial Revolution. Geneva: World Economic Forum. Retrieved from: http://www3.weforum.org/docs/ WEF_Policy_Pathways_for_the_New_Economy.pdf (accessed 27 November 2019).
} 
economy and its acquisition of the characteristics of the intellectual. In accordance with this statement, we propose the author's methodological identification of key concepts of the process of intellectualization of the global economy (Figure 1).

Intellectual leadership is based on the intellectual benefits that are formed within the intellectual ecosystem. That is, systems for which the creation, use and development of intellectual capital is a natural process. The different ability of national intellectual ecosystems to promote the development of intellectual capital determines the intellectual advantages of one country and the intellectual uncertainty of others.

The function of providing the intellectual ecosystem with intellectual capital is performed by the intellectual platform. The intellectual platform is composed of intellectual resources, both actually and potentially created by the ecosystem, and mechanisms of the intellectual property institute.

The effectiveness of an intellectual property institute can be assessed by the speed of transformation of an intellectual product into intellectual capital using intellectual technologies.

The ability of the intellectual platform to generate an intellectual product is largely dependent on the degree of intellectual comfort that can be described as the presence of conditions for: the development of an individual's intellectual ability; realization of human intellectual abilities in the process of intellectual work; awareness of the need to transform the intellectual work of man into the intellectual activity of economic entities of the intellectual ecosystem.

According to M.V. Polyakov, the basis for studying the knowledge economy is the following processes in relation to its basic unit knowledge: obtaining (acquiring accumulated or generating new knowledge); absorption from different sources; knowledge transfer such as dissemination, movement, sale, etc.; use (mainly for innovation and management $)^{22}$. The implementation of this approach in an intellectually intensive, science intensive economy, in our view, can be represented by the following scheme (Figure 2).

\footnotetext{
22 Poljakov M. V. (2017). Osoblyvosti ekonomiky znanj ta jikh projavy na rivni svitovogho ghospodarstva [Features of the knowledge economy and their manifestations at the level of the world economy]. Naukovyj visnyk Uzhghorodsjkogho nacionaljnogho universytetu [Scientific Bulletin of the Uzhgorod National University] (electronic journal), vol. 12 (2), pp. $98-102$. Retrieved from: http://www.visnyk-econom.uzhnu.uz.ua/archive/12_2_2017ua/22.pdf (accessed 25 October 2019) (in Ukrainian).
} 


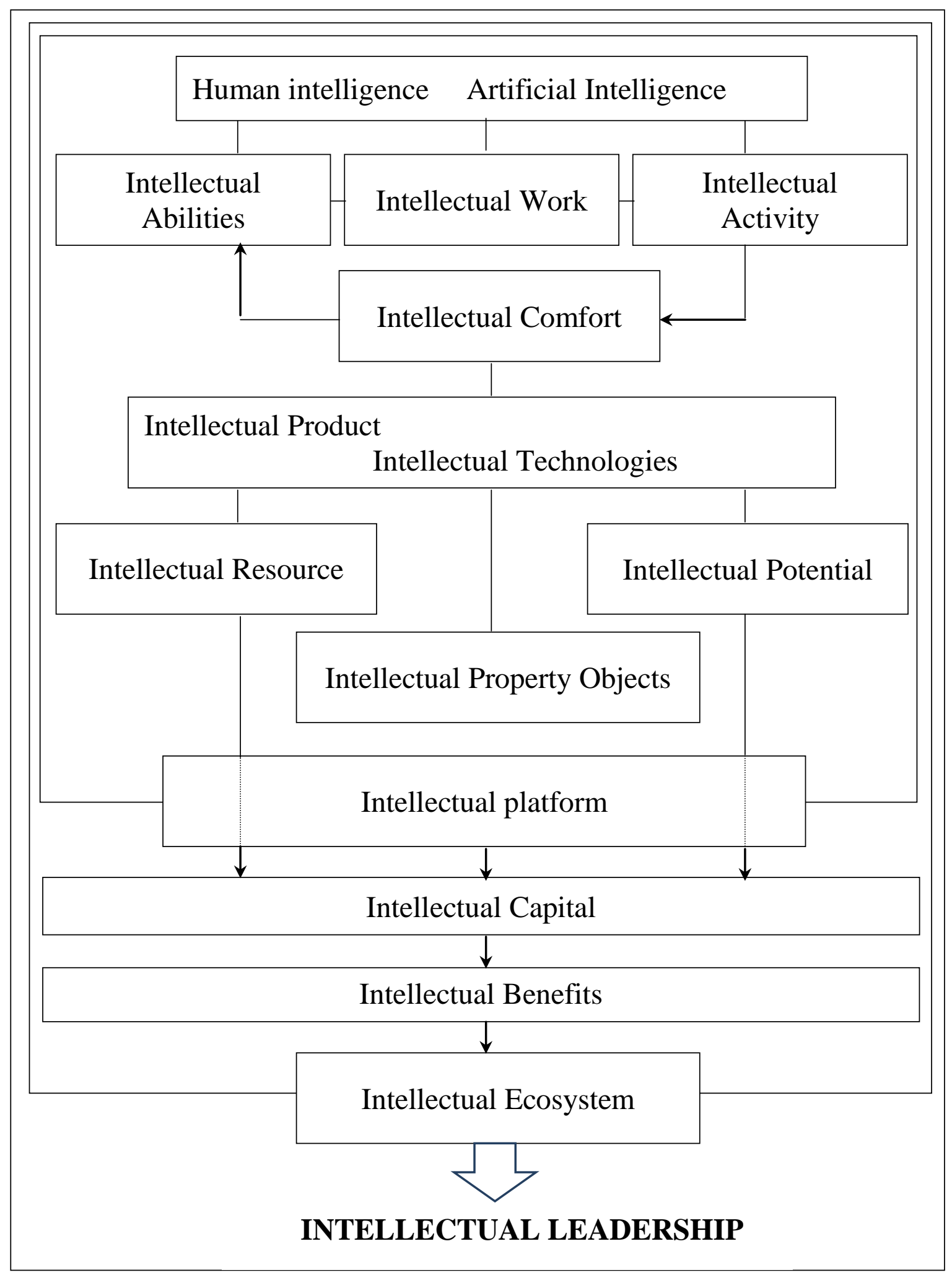

Figure 1. Methodological identification of key concepts of the global economy of intellectualization process

Source: developed by the author 


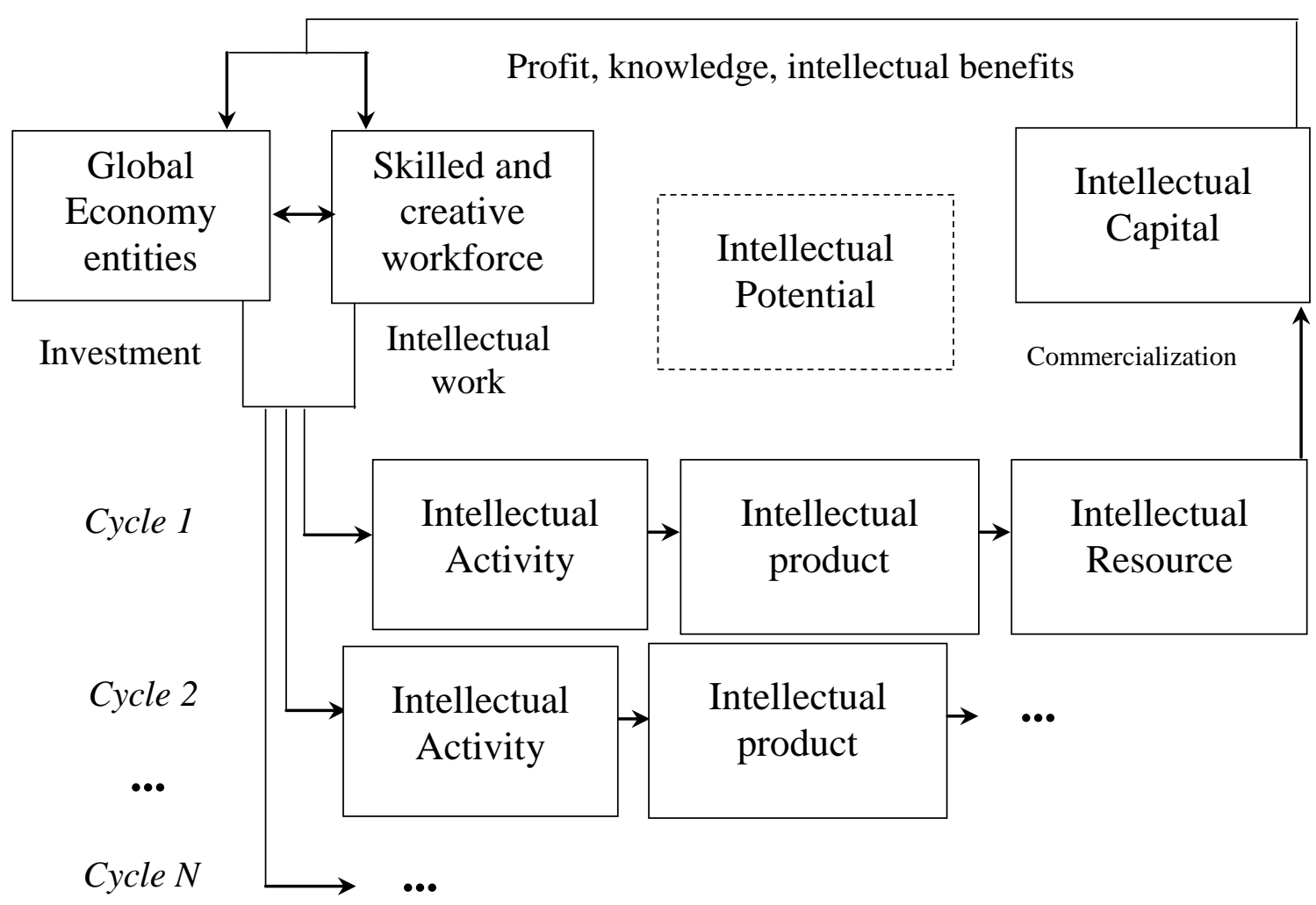

Figure 2. The cycle of expanded reproduction in the intellectual economy

Source: developed by author

The classical process of expanded reproduction of a social product in the economy is described as a sequence of stages: production $\rightarrow$ distribution $\rightarrow$ consumption $\rightarrow$ expanded production. But in our view, an intellectual economy has certain features that are determined by the characteristics of the dominant economic features of the system.

Firstly, the process of expanded reproduction in the intellectual economy is carried out in the informational way and develops cyclically in a spiral. The advent of revolutionary technologies (intellectual product) marks the beginning of a new cycle, in which the technologies of the previous cycle are already considered pre-revolutionary. The intellectual potential created and accumulated in the economy during each previous intellectual cycle constitutes an information resource for each subsequent cycle. Considering the transition to higher (more sophisticated) technologies and the accumulation (increase, increase) of intellectual potential, it can be argued that each coil turn is a new intellectual cycle. 
Secondly, each turn of the spiral decreases the total duration of the intellectual reproduction cycle, which is explained by global factor mobility, the acceleration of the life cycle of intellectual products (in particular, it is about exponential technologies; on each subsequent cycle. That is, if the duration of the full cycle of extended reproduction in the intellectual economy is equal to $\mathrm{T}$, then for each cycle $\mathrm{N}$ is inequality: $T_{N}<T_{N-1}$.

Thirdly, because of the unpredictable nature of scientific and technological progress (in particular, the spontaneity of inventions and discoveries), the distance between intellectual cycles varies considerably. Referring to the so-called «Moore's Law», it can be argued that during 1965-1998 the emergence of revolutionary technologies in the electronics industry occurred no less than every two years ${ }^{23}$. Therefore, the distance between the turns of the intellectual cycles is considered by the author to be very small, dense. During the period 1999-2007, the distance between cycles began to increase as the potential of silicon ICT was gradually exhausted by the overheating problem of ultrafast PCs. In view of G. Moore's slowdown in the development of the electronic industry since 2007, the distance between neighboring intellectual cycles is gradually increasing. The reason for this slowdown in the second decade of the XXI century G. Moore sees in the natural physical limitations: the speed of light and the atomic nature of materials ${ }^{24}$. In our opinion, today the basis of the intellectual cycle is not technologies aimed at improving the productivity and speed of operations, but intellectual products that optimize already developed technologies. Such products are differentiated by size, compactness, ergonomics, methods of cooling of technological units, quality of information visualization, degree of mobility, energy consumption level, etc. ${ }^{25}$ The next round of progress may be driven by the quantum technologies, using graphene, etc. that the ICT market is already waiting for.

Fourthly, based on the concept of the «center and periphery» of the global economy, according to the author, each coil of the spiral of

\footnotetext{
${ }^{23}$ Moore G. E. (1998). Cramming More Components onto Integrated Circuits. Proceedings of the IEEE, vol. 86, no. 1, pp. $82-85$. Retrieved from: http://www.cs.utexas.edu/ fussell/ courses/cs352h/papers/moore.pdf (accessed 2 July 2019).

${ }^{24}$ Courtland R. (2015). Gordon Moore: The Man Whose Name Means Progress. IEEE Spectrum. Retrieved from: https://spectrum.ieee.org/computing/hardware/gordon-moore-the-man-whose-namemeans-progress (accessed 3 July 2019).

${ }^{25}$ Fog A. (2015). Zakon Mura dostig predela [Moore's Law has reached its limit]. Khabr soobshchestvo IT-spetsialistov [Habr $\quad$. .NET Knowledge Base]. Retrieved from: https://habr.com/ru/post/405723/ (accessed 2 July 2019) (in Russian).
} 
expanded reproduction in fig. 2 has a tendency to gradually increase the radius of propagation. The Intellectual Center (the subjects of the global economy are intellectual leaders), as the intellectual potential increases, begins a new intellectual cycle, actively developing it. Having received an effect (profit, knowledge, intellectual advantage) that is sufficient to start a new cycle, the «intellectual center» moves from cycle $\mathrm{N}$ to cycle $(\mathrm{N}+1)$. On the one hand, intellectual leaders are interested in the rapid development of the cycle $(\mathrm{N}+1)$, that is, in reducing its duration $\mathrm{T}$, and on the other, in the global distribution of the intellectual product of previous cycles $1,2, \ldots,(\mathrm{N}-1), \mathrm{N}$ from the center to the periphery. Extension of the duration of the previous cycles due to the time for geographical spread in the global economy (in fact, in "catching up», «pursuing» economies, developing economies, etc.) and heterogeneity of economic entities in terms of readiness for new technologies, spiral of expanded reproduction in intelligence the economy takes the form of an «intellectual tornado» centered on intellectual leaders, and on the periphery, which gradually increases its radius, the countries that follow the previous «pre-revolutionary» and intellectual products (Figure 3).

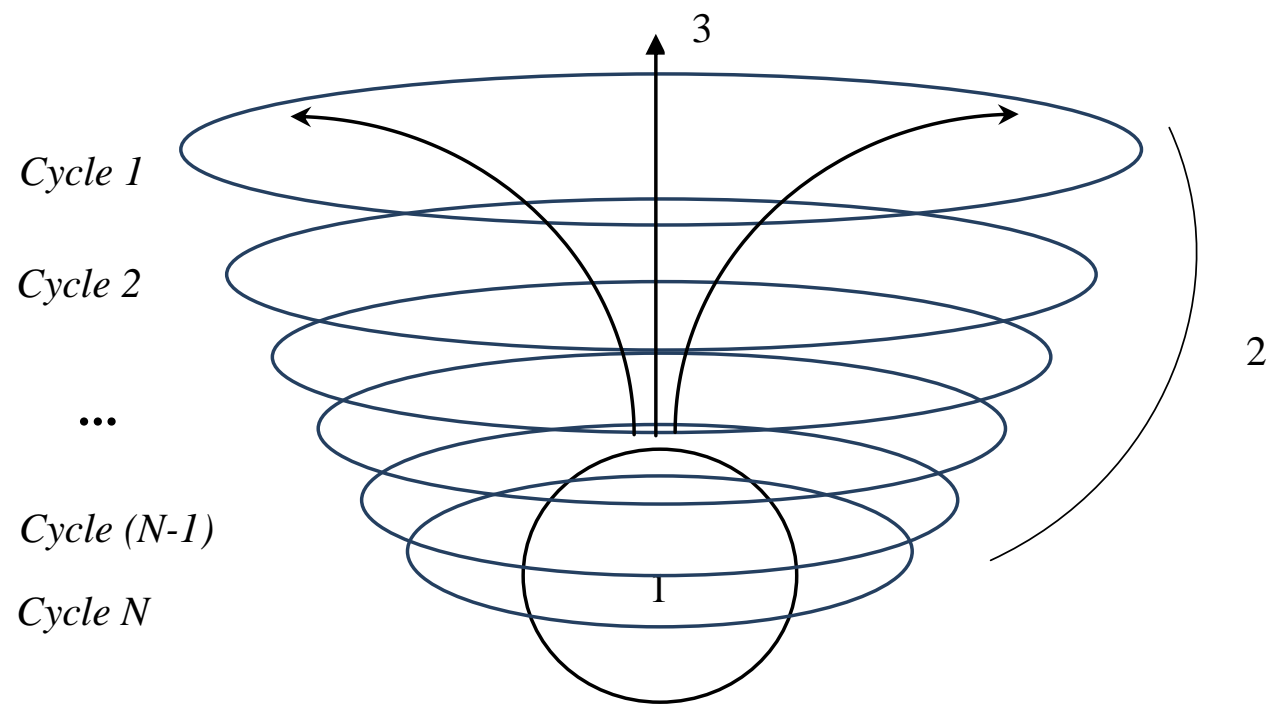

$1-$ «Intellectual center» 2 - Periphery of intellectual uncertainty 3 - Rising streams of intellectual potential

Figure 3. Intellectual Tornado Spiral in Intellectual Economy Source: developed by author 
The author explains the radius increase of the intellectual cycle by the increase in the number of groups of countries (and, consequently, by the increase of geographical distances, planes), imitating products, technologies of the intellectual center (usually represented by a limited number of national economies).

Fifthly, the subjects of the global intellectual economy that imitate the technologies of intellectual leaders are significantly differentiated in their level of readiness for these technologies. Given the complexity of the concept of «level of readiness for intellectual technology», it can be argued that its implementation occurs in conditions of intellectual uncertainty. World Bank experts have concluded that the global economy is systematically moving national economies between types of integration into global value chains based on their technological specialization. Movement is possible in two directions: from the supply of primary raw materials and further, to more technologically complex types, and in the opposite direction from the innovative to the more simplified $^{26}$. In particular, during the period 1960 2015, the countries of Austria, Canada, Finland, Ireland, Israel, Italy, the Republic of Korea, Singapore, Spain and the Czech Republic took innovative positions. China is also showing rapid technological growth, with the total number of researchers tripling between 1995 and $2007^{27}$. In the opposite direction, to the type of primary commodities, Jordan and Lesotho moved, and the whole group of countries during this period was characterized by a double movement in both directions (Swaziland, Botswana, Jamaica, Democratic People's Republic of Korea, Nicaragua and Senegal). The revealed facts, according to the author, confirm the existence of conditions of intellectual uncertainty, which explain the disposition of national economies according to the concept of «center periphery».

\section{CONCLUSIONS}

The leitmotif of the current stage of development of the global economy is the processes of its intellectualization, in particular the

\footnotetext{
${ }^{26}$ World Bank (2020). World Development Report 2020 : Trading for Development in the Age of Global Value Chains. Washington, DC: World Bank. Retrieved from: https://openknowledge.worldbank.org/handle/10986/32437 (accessed 9 January 2020).

${ }^{27}$ National Science Foundation (2013). National Science Board. Science \& Engineering Indicators 2012: Chapter 3. Science and Engineering Labor Force. Retrieved from: https://wayback.archiveit.org/5902/20170708073310/https://www.nsf.gov/statistics/seind12/pdf/c03.pdf (accessed 14 October 2019); National Science Foundation (2018). National Science Board. Science \& Engineering Indicators 2018. Retrieved from: https://www.nsf.gov/statistics/2018/nsb20181/assets/nsb20181.pdf (accessed 14 October 2019).
} 
emergence of the phenomenon «Economy 4.0». Digital infrastructure, platform interaction and rethinking the role of consumers are accelerating innovative disruption in global markets: agreements are concluded «anytime, anywhere»; rights of use prevail over property rights; platform businesses «create the foundation for the development of others»; solving complex economic problems is realized through «trustbased interaction»; the best samples are received by the global market as a way of «bringing many to the development of a single»; consumers prefer a personalized product, without «unnecessary»; value chains are shrinking as Industry 4.0 evolves; product prices are formed as a result of the service, the «terms of use»; the product combines numerous features.

The key to competitiveness of countries in global markets is intellectual leadership, which is ensured by the effectiveness of the national intellectual ecosystem and intellectual benefits. Strategic priorities of national economies are to create an environment of intellectual comfort and improve the conditions for realizing intellectual potential. The reproduction of intellectual capital in today's economy can be represented as a spiral process: the advent of revolutionary technologies initiates a new intellectual cycle; each subsequent intellectual cycle is less time-consuming than the previous one due to the exponential development of technology.

Based on the concept of «center and periphery» of the global economy, we can assume that the spiral of reproduction of intellectual capital consists of the following elements: «intellectual center», represented by a small number of countries innovative leaders; The «periphery of intellectual uncertainty» of the country, which imitates the intellectual technologies of the «center», but due to their number and heterogeneity in the level of technological, network readiness, geographical remoteness, etc., demonstrate different speed of acquisition of intellectual products of the current cycle.

As a prospect for further scientific research, the author sees the study of factors and methods of classification of countries «periphery of intellectual uncertainty», in order to clarify the intellectual disposition of countries of the global economy.

\section{SUMMARY}

Contradictory facts of the global economy development during the recession period of 2010-2019 are revealed. Catalysts and models of innovative destruction in the modern global markets are analyzed. The 
business models that emerged as a result of innovative destruction and intensification of intellectualization processes are considered. The key concepts of the process of intellectualization of the global economy have been identified. The cycle of extended reproduction in the intellectual economy is schematically depicted. The assumptions about the features of intellectual cycles in the global economy are made. The hypothesis of the size and heterogeneity of a group of countries forming the «periphery of intellectual uncertainty» has been put forward.

\section{REFERENCES}

1. Poljakov M. V. (2017). Osoblyvosti ekonomiky znanj ta jikh projavy na rivni svitovogho ghospodarstva [Features of the knowledge economy and their manifestations at the level of the world economy]. Naukovyj visnyk Uzhghorodsjkogho nacionaljnogho universytetu [Scientific Bulletin of the Uzhgorod National University] (electronic journal), vol. 12 (2), pp. 98 - 102. Retrieved from: http://www.visnykeconom.uzhnu.uz.ua/archive/12_2_2017ua/22.pdf (accessed 25 October 2019) (in Ukrainian).

2. Luk'yanenko D., Poruchnik A., Kolesov V. (ed.) (2013). Global'noe ekonomicheskoe razvitie: tendentsii, asimmetrii, regulirovanie [Global economic development: trends, asymmetries, regulation: monograph]. Kyiv: KNEU (in Russian).

3. Fog A. (2015). Zakon Mura dostig predela [Moore's Law has reached its limit]. Khabr soobshchestvo IT-spetsialistov [Habr.NET Knowledge Base]. Retrieved from: https://habr.com/ru/post/405723/ (accessed 2 July 2019) (in Russian).

4. Denis-19 (2020). Rynochnaya stoimost' Alphabet vpervye prevysila $\$ 1$ trln. [Alphabet's market value exceeded $\$ 1$ trillion for the first time]. Khabr soobshchestvo IT-spetsialistov [Habr.NET Knowledge Base]. Retrieved from: https://habr.com/ru/news/t/484298/ (accessed 17 January 2020) (in Russian).

5. Taleb N. N. (2018). Antykrykhkistj. Pro (ne)vrazlyve u realjnomu zhytti [Antifragile. Things that Gain from Disoder] / trans. from English. M. Kdymchuk. Kyiv: Nash format (in Ukrainian).

6. Deloitte Development LLC (2015). Align price with use: reducing up-front barriers with usage-based pricing. Bratislava: Deloitte University Press. Retrieved from: http://emprenderioja.es/files/ recurso/dup_3058_align-price-with-use_v2.pdf (accessed 22 October 2019). 
7. Christensen C. M. (2012). The innovator's dilemma: when new technologies cause great firms to fail. London: HarperCollins Publishers. Retrieved from: https://pdfs.semanticscholar.org/ ca36/98315441292596205d44d1a775d9cfc3fe37.pdf (accessed 4 December 2019). DOI:10.15358/9783800642816.

8. Deloitte Development LLC (2016). Connect peers: leveraging the evolving digital infrastructure to empower the edge. Bratislava: Deloitte University Press. Retrieved from: https://www2.deloitte.com/ content/dam/insights/us/articles/3061_Patterns-of-disruption-connectpeers/DUP_Patterns-of-disruption-connect-peers.pdf (accessed 25 November 2019).

9. Deloitte Development LLC (2015). Converge products: making $1+1>2$. Bratislava: Deloitte University Press. Retrieved from: https://www2.deloitte.com/content/dam/insights/us/articles/disruptivestrategy-convergence-of-products/DUP_1465_Converge-products_ vFINAL.pdf (accessed 6 December 2019).

10. Courtland R. (2015). Gordon Moore: The Man Whose Name Means Progress. IEEE Spectrum. Retrieved from: https://spectrum.ieee.org/computing/hardware/gordon-moore-the-manwhose-name-means-progress (accessed 3 July 2019).

11. Deloitte Development LLC (2015). Distributed product development: Mobilizing many to create one. Bratislava: Deloitte University Press. Retrieved from: https://www2.deloitte.com/ content/dam/insights/us/articles/disruptive-strategy-distributed-productdevelopment/DUP_1461_Distributed-product-development_vFINAL. 12.2.pdf (accessed 11 November 2019).

12. Deloitte Development LLC (2015). Expand market reach: connecting fragmented buyers and sellers-wherever, whenever. Bratislava: Deloitte University Press. Retrieved from: https://www2.deloitte.com/content/dam/insights/us/articles/disruptivestrategy-market-reach-digital-marketplaces/DUP_1459_Expand-marketreach_vFINAL.pdf (accessed 27 October 2019).

13. Fortune (2016). The Unicorn List. Retrieved from: https://fortune.com/unicorns/ (accessed 13 January 2020).

14. Fortune (2015). The Unicorn List. Retrieved from: https://fortune.com/unicorns/2015/search/?valsort=desc (accessed 13 January 2020).

15. A World Bank Group (2020). Global Economic Prospects. Slow Growth, Policy Challenges. Washington: World Bank Publications. Retrieved from: https://www.worldbank.org/en/news/feature/2020/ 
01/08/january-2020-global-economic-prospects-slow-growth-policychallenges (accessed 9 January 2020).

16. International Bank for Reconstruction and Development / World Bank (2002). Globalization, Growth, and Poverty. A World Bank Policy Research Report. Washington - New York: a copublication of the World Bank and Oxford University Press. Retrieved from: http://documents.worldbank.org/curated/en/954071468778196576/pdf/m ulti0page.pdf (accessed 29 December 2019).

17. Griffith E., Primack D. (2015). The age of unicorns. Fortune. Retrieved from: http://fortune.com/2015/01/22/the-age-of-unicorns/ (accessed 13 January 2020).

18. Ismail S., Malone M. S., van Geest Y. (2019). Exponential Organizations: Summary and Review. Retrieved from: https://lifeclub.org/books/exponential-organizations-salim-ismailmichael-s-malone-yuri-van-geest-review-summary (accessed 11 January 2020).

19. Lyons K. (2019). Google parent Alphabet is now a $\$ 1$ trillion company. The Verge. Retrieved from: https://www.theverge.com/2020/ 1/16/21069458/google-alphabet-trillion-dollar-market-cap-applemicrosoft (accessed 16 January 2020).

20. Moore G. E. (1998). Cramming More Components onto Integrated Circuits. Proceedings of the IEEE, vol. 86, no. 1, pp. 82-85. Retrieved from: http://www.cs.utexas.edu/ fussell/courses/cs352h/ papers/moore.pdf (accessed 2 July 2019).

21. National Science Foundation (2013). National Science Board. Science \& Engineering Indicators 2012: Chapter 3. Science and Engineering Labor Force. Retrieved from: https://wayback.archiveit.org/5902/20170708073310/https://www.nsf.gov/statistics/seind12/pdf/ c03.pdf (accessed 14 October 2019).

22. National Science Foundation (2018). National Science Board. Science \& Engineering Indicators 2018. Retrieved from: https://www.nsf.gov/statistics/2018/nsb20181/assets/nsb20181.pdf (accessed 14 October 2019).

23. Deloitte Development LLC (2015). Patterns of disruption: anticipating disruptive strategies in a world of unicorns, black swans, and exponentials. Bratislava: Deloitte University Press. Retrieved from: https://www2.deloitte.com/content/dam/Deloitte/nl/Documents/ technology/deloitte-nl-deloitte-patterns-of-disruption.pdf (accessed 17 November 2019). 
24. World Economic Forum (2019). Policy Pathways for the New Economy. Shaping Economic Policy in the Fourth Industrial Revolution. Geneva: World Economic Forum. Retrieved from: http://www3.weforum.org/docs/WEF_Policy_Pathways_for_the_New_ Economy.pdf (accessed 27 November 2019).

25. Raynor M. (2013). Introducing perspectives on innovation. Deloitte Consulting. Retrieved from: http://dupress.com/articles/ introducing-on-innovation (accessed 10 December 2019).

26. Lesser R., Reeves M., Harnoss J. (2016). Saving globalization and technology from themselves. BCG Henderson Institute. Retrieved from: https://www.bcg.com/publications/2016/strategy-globalizationsaving-globalization-technology-from-themselves.aspx

(accessed 21 December 2019).

27. Deloitte Development LLC (2015). Shorten the value chain: mransforming the stages of value delivery. Bratislava: Deloitte University Press. Retrieved from: https://www2.deloitte.com/content/ dam/insights/us/articles/disruptive-strategy-value-chain-models/DUP_ 3057_Shorten-the-value-chain_v2.pdf (accessed 27 November 2019).

28. Bhattacharya A., Khanna D., Schweizer C., Bijapurkar A. (2017). The New Globalization: Going Beyond the Rhetoric. BCG Henderson Institute. Retrieved from: https://www.bcg.com/publications/ 2017/new-globalization-going-beyond-rhetoric.aspx 21 December 2019).

29. Deloitte Development LLC (2015). Turn products into product platforms: providing a foundation for others to build upon. Bratislava: Deloitte University Press. Retrieved from: https://www2.deloitte.com/ content/dam/insights/us/articles/disruptive-strategy-product-platforms/ DUP_3056_Products-to-platforms_v2.pdf (accessed 25 November 2019).

30. Deloitte Development LLC (2015). Unbundle products and services: giving you just what you want, nothing more. Bratislava: Deloitte University Press. Retrieved from: https://www2.deloitte.com/ content/dam/insights/us/articles/disruptive-strategy-unbundling-strategystand-alone-products/DUP_3033_Unbundle-products_v2.pdf (accessed 1 December 2019).

31. Deloitte Development LLC (2015). Unlock assets from adjacent markets: cultivating opportunities on the edge. Bratislava: Deloitte University Press. Retrieved from: https://www2.deloitte.com/content/ dam/insights/us/articles/disruptive-strategy-unlock-assets-adjacent- 
markets/DUP_3059_Unlock-adjacent-assets_vFINAL.pdf (accessed 24 December 2019).

32. Bhattacharya A., Bürkner H.-P., Bijapurkar A. (2016). What you need to know about globalization's radical new phase. $B C G$ Henderson Institute. Retrieved from: https://www.bcg.com/publications/ 2016/globalization-growth-what-need-know-globalization-radical-newphase.aspx (accessed 27 December 2019).

33. World Bank (2020). World Development Report 2020 : Trading for Development in the Age of Global Value Chains. Washington, DC: World Bank. Retrieved from: https://openknowledge.worldbank.org/ handle/10986/32437 (accessed 9 January 2020).

\section{Information about the author:} Nyameshchuk A. V. $\mathrm{PhD}$ (Economics), Associate Professor, Doctoral Candidate. Kyiv National Economic University named after Vadym Hetman, Ukraine ORCID: https://orcid.org/0000-0003-3199-8988 